\title{
Deposition of Coating to Protect Waste Water Reservoir in Acidic Solution by Arc Thermal Spray Process
}

\author{
Han-Seung Lee, ${ }^{1}$ Jin-ho Park, ${ }^{1}$ Jitendra Kumar Singh ${ }^{D},{ }^{1}$ and Mohamed A. Ismail ${ }^{2}$ \\ ${ }^{1}$ Department of Architectural Engineering, Hanyang University, 1271 Sa 3-dong, Sangrok-gu, Ansan 15588, Republic of Korea \\ ${ }^{2}$ Department of Civil and Construction Engineering, Faculty of Engineering and Science, Curtin University Malaysia, CDT 250, \\ 98009 Miri, Sarawak, Malaysia
}

Correspondence should be addressed to Jitendra Kumar Singh; jk200386@hanyang.ac.kr

Received 30 January 2018; Accepted 29 March 2018; Published 23 April 2018

Academic Editor: Jan Cizek

Copyright $\odot 2018$ Han-Seung Lee et al. This is an open access article distributed under the Creative Commons Attribution License, which permits unrestricted use, distribution, and reproduction in any medium, provided the original work is properly cited.

\begin{abstract}
The corrosion characteristics of 304 stainless steel (SS) and titanium (Ti) coatings deposited by the arc thermal spray process in $\mathrm{pH}$ 4 solution were assessed. The Ti-sprayed coating exhibits uniform, less porous, and adherent coating morphology compared to the SS-sprayed coating. The electrochemical study, that is, electrochemical impedance spectroscopy (EIS), revealed that as exposure periods to solution were increased, the polarization resistance $\left(R_{\mathrm{p}}\right)$ decreased and the charge transfer resistance $\left(R_{\mathrm{ct}}\right)$ increased owing to corrosion of the metallic surface and simultaneously at the same time the deposition of oxide films/corrosion on the SS-sprayed surface, while Ti coating transformed unstable oxides into the stable phase. Potentiodynamic studies confirmed that both sprayed coatings exhibited passive tendency attributed due to the deposition of corrosion products on SS samples, whereas the Ti-sprayed sample formed passive oxide films. The Ti coating reduced the corrosion rate by more than six times compared to the SS coating after $312 \mathrm{~h}$ of exposure to sulfuric acid- $\left(\mathrm{H}_{2} \mathrm{SO}_{4^{-}}\right)$contaminated water solution, that is, $\mathrm{pH} 4$. Scanning electron microscope (SEM) results confirmed the uniform and globular morphology of the passive film on the Ti coating resulting in reduced corrosion. On the other hand, the corrosion products formed on SS-sprayed coating exhibit micropores with a net-like microstructure. X-ray diffraction (XRD) revealed the presence of the composite oxide film on Ti-sprayed samples and lepidocrocite $(\gamma$-FeOOH$)$ on the SS-coated surface. The transformation of $\mathrm{TiO}$ and $\mathrm{Ti}_{3} \mathrm{O}$ into $\mathrm{TiO}_{2}\left(\right.$ rutile and anatase) and $\mathrm{Ti}_{3} \mathrm{O}_{5}$ after $312 \mathrm{~h}$ of exposure to $\mathrm{H}_{2} \mathrm{SO}_{4}$ acid reveals the improved corrosion resistance properties of Ti-sprayed coating.
\end{abstract}

\section{Introduction}

Concrete is a material that can withstand and sustain exposure to an aggressive environment over long periods and resist deterioration. Therefore, concrete is a reliable and durable construction material with versatile applications in waste water reservoirs, buildings, bridges, towers, roads, and so on. However, it is also a porous material, which means that aggressive ions such as $\mathrm{Cl}^{-}, \mathrm{CO}_{3}{ }^{-}$, and $\mathrm{SO}_{4}{ }^{-}$can slowly or steadily penetrate and move toward the embedded steel rebar, thus causing corrosion that leads to premature concrete failure [1-3].

The major factor in concrete deterioration is acidic impurities in its surrounding [4]. Different external coatings have been applied to protect concrete and the embedded steel rebar. Swamy and Tanikawa used acrylic rubber as an external coating material for concrete in accelerated wet-dry and saline environments [5]. They found that this coating withstood saline and ozone exposures but suffered extensive cracking when exposed to ultraviolet radiation. Therefore, polymeric coating is not suitable for concrete coating because of vast differences in the thermal contraction and expansion coefficients between the concrete and polymer.

The presence of sulfur-reducing bacteria in waste water makes it acidic $[6,7]$. The minimum $\mathrm{pH}$, that is, 4.5 , of waste water can be obtained [8] depending on the source and environment where it is produced.

The acidity of waste water influences the deterioration of the concrete and steel rebar. Therefore, to protect these from corrosion, SS grouting and anchoring have been widely used $[6,7]$. SS plates are used in waste water reservoirs to protect the concrete and embedded steel rebar. But cost factors are 
affecting the use of such steel plates on the outer surface of concrete. Nonetheless, SS plates and other protective methods or surface treatments are frequently used to protect the concrete and waste water reservoirs owing to their high resistance to corrosion [9]. Also, the nanostructured and PVD coatings were used in high-speed drilling and cutting instruments to enhance the mechanical properties of tools $[10,11]$.

A method to deposit coatings onto the concrete surface is an important factor in the deposition of high melting point corrosion-resistant metals. One view is that the coating process should be considered for deposition on account of its feasibility and applicability. High corrosion-resistant materials such as SS, nickel (Ni), tungsten (W), molybdenum (Mo), chromium (Cr), and Ti need a specific deposition process. The arc thermal spray process is suitable and feasible for depositing these metals onto any substrate [12-17].

The arc thermal spray process is an easy process for the deposition of coatings onto concrete and steel substrates. This process involves arc spraying with twin metal wires on oppositely charged tips that use atomized hot air to deposit the coating onto the substrate [12]. During the coating process, melted metal droplets are deposited and form a thick layer on the substrate. During coating deposition, pores/defects are formed, which is an inherent property of the arc thermal spray process [13-15]. Pore formation depends on the metal to be used and spraying parameters of the process.

Our recently published paper showed that the 316L SS coating applied on the concrete substrate, and then sealed with alkyl epoxide, effectively protected the surface from corrosion in $\mathrm{pH} 4,5$, and 6 solutions. The most destructive was the $\mathrm{pH} 4$ solution because of its higher acidity compared with the other solutions [16]. In the $\mathrm{pH} 5$ solution, the tested coatings exhibited the highest corrosion resistance because of the presence of undissociated water molecules that formed a protective passive film on the coating surface. This experiment was carried out for instantaneous exposure; there is currently no study on prolonged exposure.

The $\mathrm{pH} 4$ solution is an aggressive environment, and the surface is expected to deteriorate dramatically. This $\mathrm{pH}$ solution increases the risk of corrosion due to its more acidic nature. If a coating can withstand this $\mathrm{pH}$, then it can extend the protection of a waste water reservoir against corrosion.

The present investigation aims to protect the concrete of a waste water reservoir from deterioration, spalling, and thawing during prolonged exposure to an acidic environment using surface treatment with 304 SS and Ti metallic coatings by an arc thermal spray process. This communication is an advancement of our earlier published work [16]. The acidic condition was simulated by mixing $0.1 \mathrm{M} \cdot \mathrm{H}_{2} \mathrm{SO}_{4}$ $(\mathrm{pH}=1)$ in distilled water to reduce the $\mathrm{pH}$ of distilled water from 6.5 to 4.0 at $25^{\circ} \mathrm{C}$. Assessments of the corrosion resistance of these coatings were carried out using different electrochemical techniques.

\section{Experimental Section}

2.1. Process of Coating. The $304 \mathrm{SS}$ and $\mathrm{Ti}$ coatings were applied to grit-blasted mild steel containing carbon $(C)=0.24$,

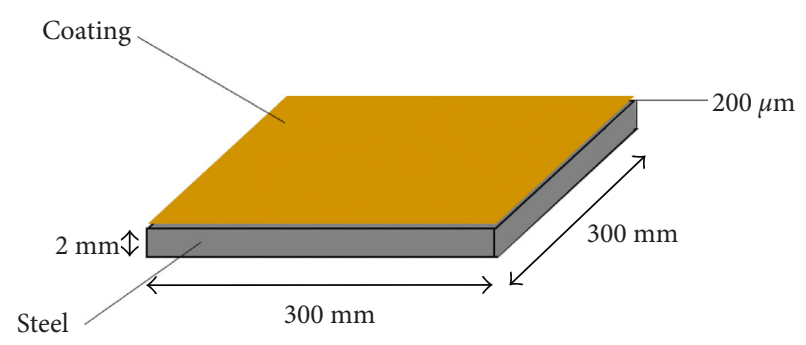

FIgURE 1: Sketch of coating applied on the steel substrate.

silicon $(\mathrm{Si})=0.26$, manganese $(\mathrm{Mn})=0.95$, phosphorus $(\mathrm{P})=$ 0.016 , sulfur $(\mathrm{S})=0.008$, copper $(\mathrm{Cu})=0.02$, chromium $(\mathrm{Cr})=0.04$, nickel $(\mathrm{Ni})=0.03$, and iron $(\mathrm{Fe})=$ balance $(w \mathrm{t} . \%)$ and to concrete substrates by an arc thermal spray process. The coating deposited onto the steel substrate was used to study its electrochemical and physical characteristics as shown in Figure 1, while the coating deposited onto the concrete surface was used for bond adhesion measurement.

Concrete is a low-conducting material that cannot be used for electrochemical studies. Hence, it was not considered for electrochemical studies. A $1.6 \mathrm{~mm}$ diameter wire of 304 SS and commercially pure $\mathrm{Ti}$ was used for metal spraying in the arc thermal spraying process to deposit the coatings onto the substrates.

Prior to the deposition of coatings, the steel substrate was pickled with $10 \% \mathrm{v} / \mathrm{v} \mathrm{HCl}$, thoroughly washed with distilled water, dried, and finally grit-blasted with 0.7 and $0.8 \mathrm{~mm}$ steel balls using a pressure machine at $0.7 \mathrm{MPa}$. Coating thickness was measured using a nondestructive Elcometer 456 dry film thickness gauge at different locations on the steel and concrete substrate; the thickness was approximately $200 \mu \mathrm{m}( \pm 5 \mu \mathrm{m})$.

The coatings were applied to the substrate by the arc thermal spray gun (LD/U3 electric arc wire spray gun, Oerlikon MetcoTM, Switzerland) process using 304 SS and Ti wires with a circular slit of hot and compressed air [17-20]. The melted metal particles diffused onto the substrate and cooled at room temperature, resulting in the formation of pores/defects on the coating.

The spraying of metallic coating on the target substrate was carried out by keeping the sample $20 \mathrm{~cm}$ away from the spray gun at an air pressure of 6 bar. The spraying voltage and current were maintained at approximately $30 \mathrm{~V}$ and $200 \mathrm{~mA}$, respectively [15, 21-23].

After applying the coating on the concrete substrate, coating adhesion was measured according to the KS F4716 test method [24]. In this process, a $300 \mathrm{~mm} \times 300 \mathrm{~mm} \mathrm{sec-}$ tion of the coated substrate was taken for the adhesion test (Figure 1).

2.2. Electrochemical Experiments. Electrochemical experiments were carried out on the deposited coatings and 304 SS plate. For the sake of comparison with deposited coating, we have chosen to characterize the 304 SS plate.

To perform the electrochemical experiments, a solution was prepared in double distilled water by adding a few drops of $0.1 \mathrm{M} \cdot \mathrm{H}_{2} \mathrm{SO}_{4}$ to reduce the $\mathrm{pH}$ to 4 at $25^{\circ} \mathrm{C}$. These 


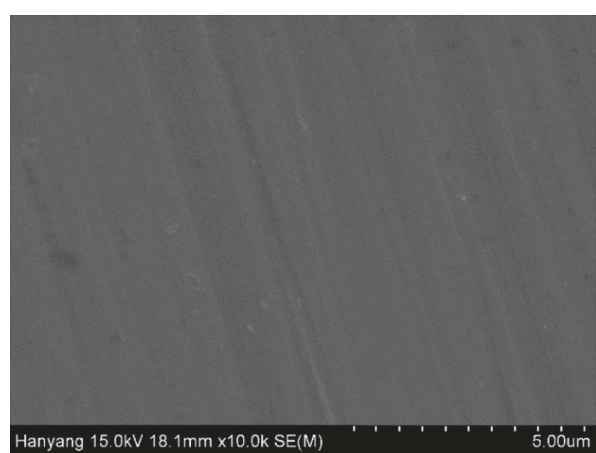

(a)

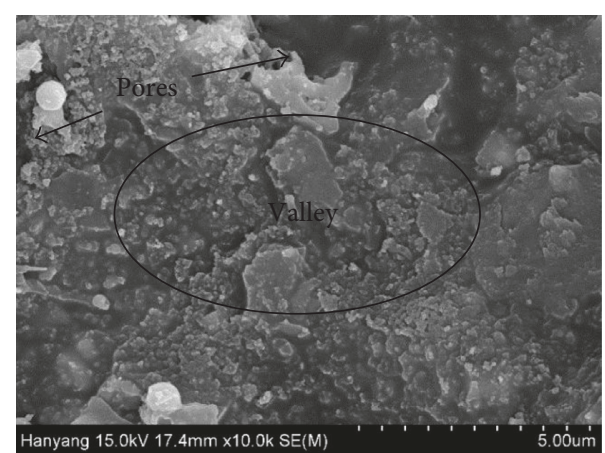

(b)

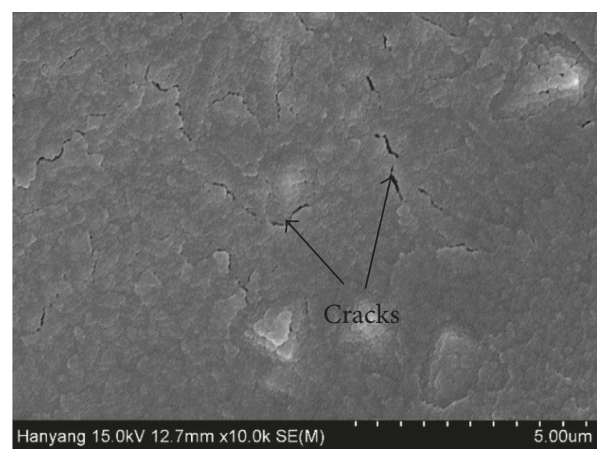

(c)

FIGURE 2: FE-SEM images of the (a) SS plate, (b) SS-sprayed surface, and (c) Ti-sprayed surface.

experiments were performed using three electrode systems [17], where the coating acted as the working electrode (WE), the platinum wire acted as the counterelectrode, and the silver/silver chloride $(\mathrm{Ag} / \mathrm{AgCl})$ acted as the reference electrode. The area of the WE was $0.78 \mathrm{~cm}^{2}$ and was fixed for all the samples.

EIS experiments were carried out by changing the frequency of a $10 \mathrm{mV}$ sinusoidal voltage from $100 \mathrm{kHz}$ to $0.01 \mathrm{~Hz}$. The potentiodynamic experiments were performed from $-0.4 \mathrm{~V}$ to $+0.8 \mathrm{~V}$ versus $\mathrm{Ag} / \mathrm{AgCl}$ at $1 \mathrm{mV} / \mathrm{s}$ scan rate. The potentiostat used in this study was a VersaSTAT (Princeton Applied Research, Oak Ridge, TN, USA), and data analysis was carried out using the Metrohm Autolab Nova 1.10 software.

The 304 SS plate was abraded with an emery paper from $60 \mu \mathrm{m}$ up to $300 \mu \mathrm{m}$ to remove the native oxides from the surface prior to starting electrochemical experiments. All electrochemical experiments were conducted in triplicate at room temperature $\left(27 \pm 1^{\circ} \mathrm{C}\right)$ to generate reproducible data.

2.3. Characterization of Coating. The morphology of the deposited coatings and 304 SS plate was determined by an SEM (Philips XL 30) operated at $15 \mathrm{kV}$. Prior to taking the images of the samples, these were coated with platinum to increase their conductivity and avoid a charging effect.

XRD (Philips X'Pert-MPD) studies of the coatings and 304 SS plate were performed using $\mathrm{Cu}-\mathrm{K} \alpha$ radiation $(\lambda=1.54059 \AA)$ generated at $40 \mathrm{kV}$ and $100 \mathrm{~mA}$. The scanning rate to scan XRD data from 10 to $90^{\circ}$ was at $0.5^{\circ} / \mathrm{min}$.

\section{Results and Discussion}

3.1. Adhesion Test of Sprayed Coatings. Adhesion measurements were carried out after deposition of coatings onto the concrete surface by arc thermal spraying. This was measured for four samples, and the average was calculated. The average adhesion values of 304 SS- and Ti-sprayed surfaces were 3.39 and $2.72 \mathrm{MPa}$, respectively. The SS-sprayed coating exhibits higher adhesion values than Ti-sprayed coating. The standard deviation of SS- and Ti-sprayed coating was calculated, and these were 0.40 and $0.24 \mathrm{MPa}$, respectively. This indicates that SS coating adhered strongly to the concrete surface, whereas Ti-sprayed coating adhered 1.25 times lesser than the 304 SS coating. The higher adhesion values of the SS coating may be attributed to small interfacial separation between the concrete substrate and metallic particles, while that for Ti was large [25].

3.2. Morphology of SS Plate and Sprayed Coating. The morphologies of the 304 SS plate and deposited coatings on the mild steel substrate were characterized by SEM. Figure 2 shows the SEM images of the deposited coatings and 304 SS plate. The SS plate surface exhibited a smooth and very finely scratched line (Figure 2(a)), while the deposited coatings had many cracks and defects over the surfaces (Figures 2(b) and (c)).

The scratched line on the plate surface was caused by abrasion with an emery paper up to $300 \mu \mathrm{m}$ because this grade of the emery paper is hard and makes some fine 


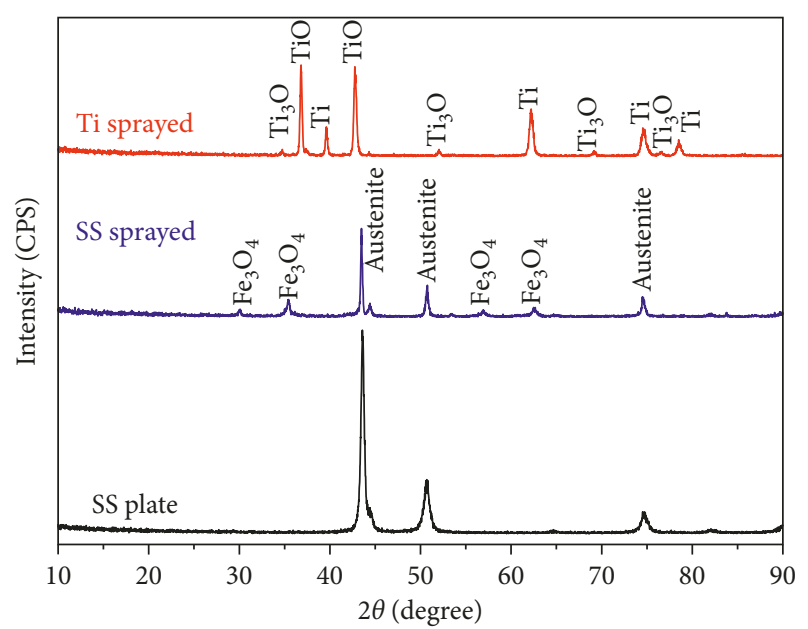

FIGURE 3: XRD of the SS plate and sprayed coatings by the arc thermal spray process $\left(0.5^{\circ} / \mathrm{min}\right)$.

defects/lines on the surface. The SS-sprayed surface showed coagulated valleys and uneven deposition, while the Tisprayed surface showed uniform, nanosized globular, and fine elongated cracks. The fine cracks on the Ti-sprayed surface might be due to formation of thin and nanoscaled brittle oxides. The morphology of SS-sprayed coating can be attributed due to the sudden cooling of melted metal particles at room temperature $\left(27 \pm 1^{\circ} \mathrm{C}\right)$.

The microstructure of the SS-sprayed coating (Figure 2(b)) could allow the deposition of aggressive ions, water, and moisture particles on valleys, which cause localized or crevice corrosion. The Ti-sprayed coating also exhibited fine cracking on the surface but had little influence on the deposition of water molecules. Owing to the smooth microstructure of the Ti coating, water molecules may slide off the surface.

\subsection{Phase Identification of SS Plate and Sprayed Coatings by} $X R D$. XRD was performed to determine the phases present in the coatings and plate surfaces. The results are plotted between $2 \theta=10^{\circ}$ and $90^{\circ}$ versus intensity in counts per second (CPS) and shown in Figure 3. The SS plate and sprayed surfaces exhibited the austenite phase of the Fe-CrNi alloy, that is, 304 SS $[26,27]$. Besides this phase in the SSsprayed surface, magnetite $\left(\mathrm{Fe}_{3} \mathrm{O}_{4}\right)$ is also observed, and it is due to the partial oxidation of coating during the spraying process.

XRD of Ti-sprayed coating showed $\mathrm{Ti}$ [28] and two oxides such as $\mathrm{TiO}$ and $\mathrm{Ti}_{3} \mathrm{O}$, which were formed due to higher melting point of it than SS where there are possibilities to oxidize the deposited coating. The another reason to oxidize the $\mathrm{Ti}$ is high affinity of it with atmospheric oxygen and thus to form surface oxide films such as $\mathrm{TiO}$ or $\mathrm{Ti}_{3} \mathrm{O}$. The formation of these two oxides of $\mathrm{Ti}$ in open atmosphere has also been reported by other researchers $[29,30]$. However, these oxides are amorphous, brittle, and unstable in in vivo conditions which easily can be removed simply by brushing with soft tissues [31-33].

\subsection{Electrochemical Studies of SS Plate and Sprayed Coating in pH 4 Solution}

3.4.1. EIS Studies. The samples were immersed in $\mathrm{pH} 4$ solution for different periods of exposure. EIS was carried out to study their corrosion characteristics. These results are shown in Figures 4 and 5. The electrical equivalent circuit (EEC) is shown in the corresponding Nyquist plots. The EEC of the SS plate exposed to the $\mathrm{pH} 4$ solution for $1 \mathrm{~h}$ is shown in Figure 4(a). In the Nyquist plot of the SS plate, the sample after $1 \mathrm{~h}$ of exposure is differentiated by two depressed semicircle loops such as one at high while another at the lower studied frequency. For more clarity of plots at high frequency, the Nyquist result of samples is shown in Figure S1 (supplementary figure). These results can be explained either by the heterogeneity of the solid surface or by the dispersion of some physical properties. The interface of the surface cannot be considered as an ideal capacitor due to heterogeneity of the surface, and it may involve a constant-phase element (CPE) as a substitute of the ideal capacitor. The first EEC consists of the solution resistance $\left(R_{\mathrm{s}}\right)$, polarization resistance $\left(R_{\mathrm{p}}\right)$, and CPE1 due to the metal surface and nonideal double-layer capacitance behaviour [34-36]. The $R_{\mathrm{p}}$ and CPE1 are parallel to each other. However, the second EEC contains the charge transfer resistance $\left(R_{\mathrm{ct}}\right)$ and CPE2. The formation of $R_{\mathrm{ct}}$ may be due to formation of the protective passive layer on the SS plate surface in acidic $\mathrm{pH}$ solution after $1 \mathrm{~h}$ of exposure. These two EECs are connected in series to each other.

The EECs for the SS- and Ti-sprayed coating systems are somewhat different from the SS plate, and they are inserted in Figure 4(a). The different EECs for these coatings may be attributed to the inherent property of the arc thermal spray process, where coatings suffer from surface defects. Due to reaction on the metal surface, $R_{\mathrm{ct}}$ participated owing to initiation of the corrosion process in acidic $\mathrm{pH}$ solution. The reaction on the metal surface caused by $R_{\mathrm{ct}}$ led to the formation of a passive/oxide layer on the metal surface, which increased the resistance and reduced the corrosion reaction. The CPE1 due to a nonideal behaviour of the coating surface and $R_{\mathrm{p}}$ are parallel to each other, while another EEC is connected in series to $R_{\mathrm{p}}$ which contains CPE2 and $R_{\mathrm{ct}}$ [15]. The CPE2 and $R_{\mathrm{ct}}$ are parallel to each other.

The Nyquist plots reveal the real characteristics of the samples after $1 \mathrm{~h}$ of exposure (Figure 4(a)). The samples were exposed to the solution for $1 \mathrm{~h}$ to stabilize the potential; thereafter, EIS measurements were performed.

Figure 4(a) shows the two semicircle loops in the Nyquist plots exhibited by coated samples. The SS- and Ti-sprayed coatings show zigzag and scattered plots which might be due to low conductivity of electrolytes, deposition of defective coating, formation of a defective passive film, and the presence of more resistive elements such as $\mathrm{Ti}$ in Ti-sprayed coating while $\mathrm{Cr}$ and $\mathrm{Ni}$ in SS-sprayed samples [37-40]. These results are attributed to the fact that both sprayed samples exhibit capacitive properties due to the presence of defects. However, the Ti coating imposed a resistance greater than the SS coating due to the formation of a passive/oxide film with capacitive behaviour which enabled surface resistance to penetrate the ions of the acidic solution. 


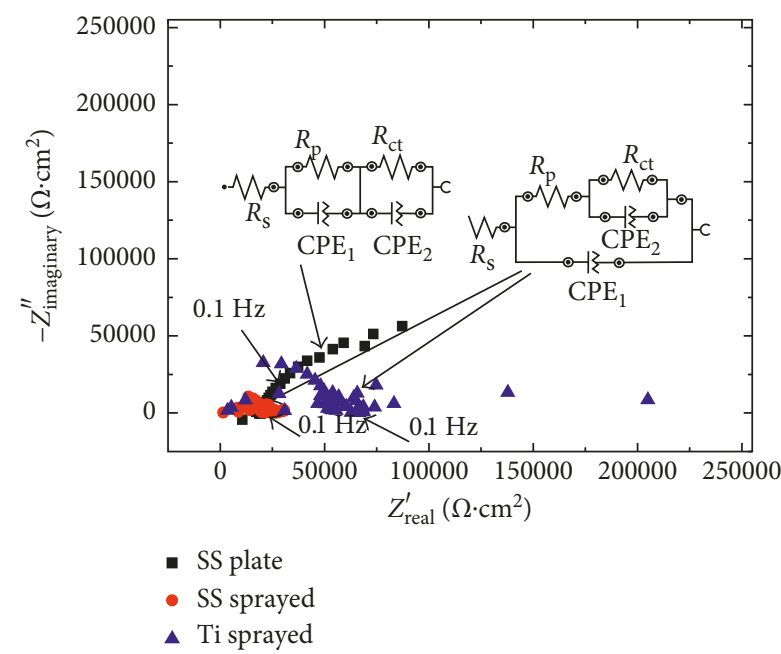

(a)

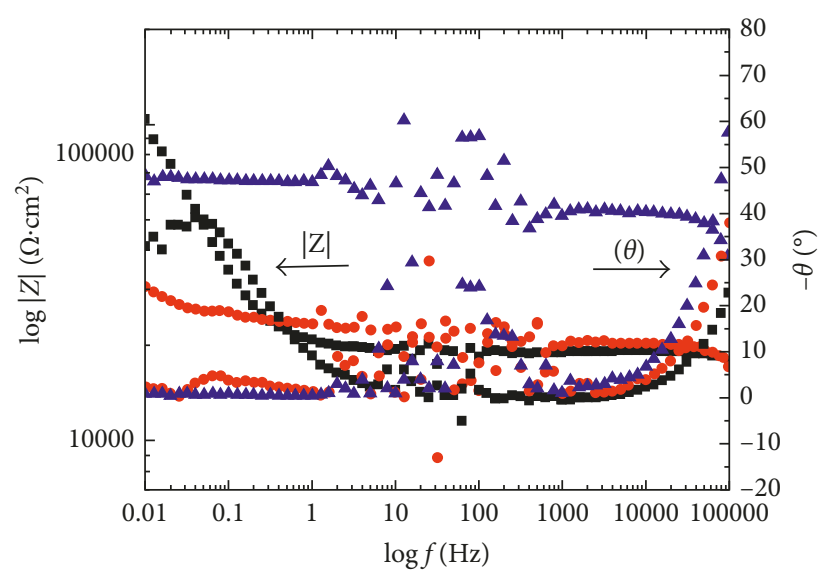

- SS plate

- SS sprayed

- Ti sprayed

(b)

Figure 4: Impedance spectra: (a) Nyquist and (b) Bode $|Z|$ and $(\theta)$ of the SS plate and sprayed coatings in pH 4 solution after $1 \mathrm{~h}$ of exposure $(100 \mathrm{kHz}$ to $0.01 \mathrm{~Hz})$.

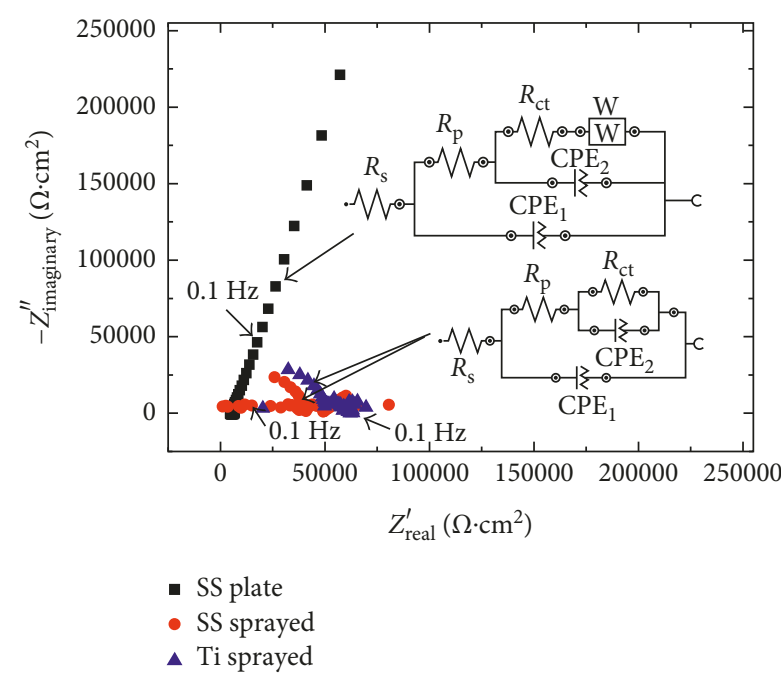

(a)

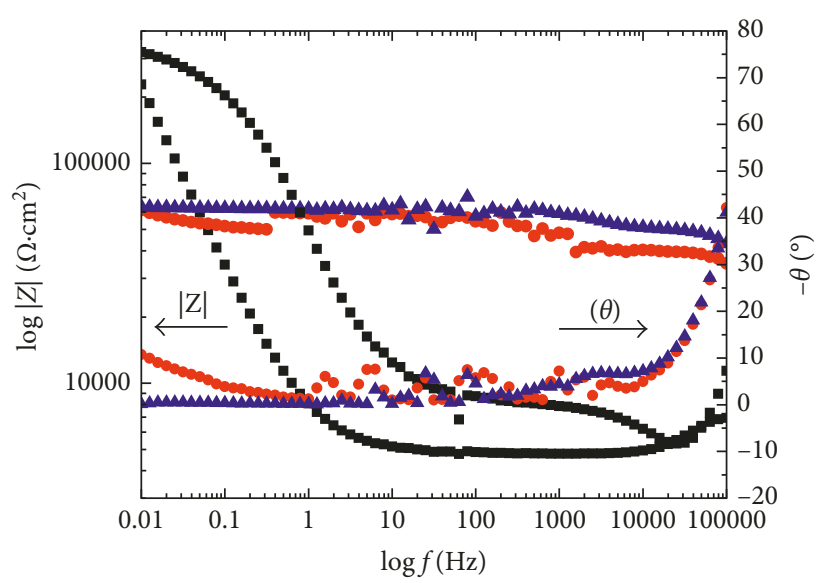

- SS plate

- SS sprayed

- Ti sprayed

FIGURE 5: Impedance spectra: (a) Nyquist and (b) Bode $|Z|$ and $(\theta)$ of the SS plate and sprayed coatings in pH 4 solution after $312 \mathrm{~h}$ of exposure $(100 \mathrm{kHz}$ to $0.01 \mathrm{~Hz})$.

In the sulfuric acid solution, the Ti surface tends to form defective passive films with high resistance. Similar results have been observed by Baron et al. on TiAlV and TiAlNb alloys in Tyrode's solution [41].

The dimensions of the semicircle loop of SS plate samples clearly show high capacitive property that enables the surface to resist the penetration of the solution. The capacitive property of the passive film on the SS plate was attributed to the formation of $\mathrm{Cr}$-enriched oxide and $\mathrm{NiO}$ in the $\mathrm{H}_{2} \mathrm{SO}_{4^{-}}$ contaminated water solution [42].

The dimensions of the semicircle loops of SS- and Tisprayed coatings were less than those of the SS plate because the sprayed samples were more susceptible to corrosion, owing to the formation of defects/pores on the coating surface in the solution after $1 \mathrm{~h}$ of exposure.

The impedance at low frequency $(0.01 \mathrm{~Hz})$ and the phase $\theta\left({ }^{\circ}\right)$ of Bode plots were plotted against $\log |Z|\left(\Omega \cdot \mathrm{cm}^{2}\right)$ versus $\log f(\mathrm{~Hz})$ and $\theta\left({ }^{\circ}\right)$ versus $\log f(\mathrm{~Hz})$ in Figure 4(b), respectively. The impedance values of the SS plate sample were greater than those of the SS and Ti coatings. The SS coating exhibited lower impedance values because of the presence of more defects/pores at locations where the chances of penetration by the acidic solution are high, and this initiated the deterioration of the coating.

From the $\log |Z|\left(\Omega \cdot \mathrm{cm}^{2}\right)-\log f(\mathrm{~Hz})$ Bode plots (Figure 4(b)), it can be seen that, at high frequency $(100 \mathrm{kHz})$, resistance was 
moreover identical to that observed at low frequency, that is, $0.01 \mathrm{~Hz}$, which might be attributed to the low conductivity of acidic $\mathrm{pH}$ solution.

In this study, the solution was prepared by adding a few drops of $0.1 \mathrm{M} \cdot \mathrm{H}_{2} \mathrm{SO}_{4}$ to distilled water. The solution conductivity was very low, which caused the resistance in total impedance. The conductivity of the solution is an important parameter that must be considered in electrochemical studies. However, the Ti coating exhibited higher impedance than the SS coating due to formation of a thick and protective passive oxide film. The low impedance values of the sprayed samples are due to the presence of more defects or less interfacial resistance between the splats of coating than on the SS plate sample.

The surface finish and coating microstructure play an important role to determine the corrosion resistance properties of materials in the solution. The $\mathrm{pH} 4$ solution is very aggressive and causes localized or pitting corrosion of the oxide films formed during exposure [43-45].

The defective parts of coatings can function as anode, while the remaining acts as a cathode, resulting in the formation of microgalvanic cells on the surface. The presence of microgalvanic cells enhances the corrosion rate of materials; thus, there is a chance of getting low impedance. Such observations are found in SS- and Ti-sprayed coatings. In view of the above, it can be observed that the SS coating exhibited valley-type deposits (Figure 2(b)) where the acidic solution could stagnant/deposit and cause localized and crevice corrosion. During the initial period of exposure, both sprayed coatings had defects that resulted in lower impedance values than the SS plate surface.

The SS plate shows a $-40^{\circ}$ shift of the phase angle maxima at the lower studied frequency and reveals high resistance to corrosion in the $\mathrm{pH} 4$ solution (Figure 4(b)). On the other hand, Ti and SS coatings exhibited $-1^{\circ}$ and $-2^{\circ}$ shifts, respectively, which indicate their susceptibility to corrosion during the initial period of exposure [37]. In the middle frequency range, the samples exhibited scattering which might be due to the capacitive response of the defective passive film that was formed during exposure of the samples to $\mathrm{H}_{2} \mathrm{SO}_{4}$ solution [38-40].

The shifting of maxima at the higher studied frequency $(100 \mathrm{kHz})$ is due to the deposition of corrosion products on the SS-sprayed sample, whereas on the Ti-coated sample, it is due to formation of the resistive passive film. It can be seen that the $\mathrm{Ti}$ coating exhibited approximately $-57^{\circ}$ shift followed by the SS coating at $-38^{\circ}$, while the SS plate had the lowest shift at $-23^{\circ}$. These results indicate that the Ti-sprayed surface formed a protective passive film owing to reaction at the coating/solution interface. Thus, the Ti coating exhibited higher resistance to the acidic solution.

As the exposure periods were extended, the increased dimensions of semicircle loops in the Nyquist plots showed increased corrosion resistance [46]. The bigger loops in the Nyquist plots reveal high resistance to corrosion in any environment. Such results can be seen from Figure 5(a) after $312 \mathrm{~h}$ of exposure to $\mathrm{pH} 4$ solution. The EEC for the SS plate after $312 \mathrm{~h}$ of exposure is inserted in Figure 5(a). The Warburg impedance (W) is caused by diffusion of the protective passive layer on the SS plate surface in the $\mathrm{H}_{2} \mathrm{SO}_{4}$ contaminated solution. $R_{\mathrm{ct}}$ and $\mathrm{W}$ are parallel to the CPE2 [16].

At longer periods of exposure $(312 \mathrm{~h})$, many parameters are involved owing to the complex reaction process on the metal/solution interface.

All samples exhibited two loops in the Nyquist plots, one at higher and another at lower frequencies. The loops formed at higher and lower frequencies because of the solution resistance and the reaction at the metal/solution interface, respectively [47-51]. As the exposure period is increased, strengthening of the passive film on the SS plate may occur [52]. However, in case of $\mathrm{Ti}$, there is a possibility of formation of the protective passive film due to transformation of unstable titanium oxides into stable oxides, while on SSsprayed samples, it is due to deposition of corrosion products on the coating defects in $\mathrm{H}_{2} \mathrm{SO}_{4}$-contaminated water solution [53]. The two semicircle loops of $\mathrm{Ti}$ and SS coatings were successfully distinguished from each other for this exposure period. Therefore, the Ti coating had provided greater protection than the SS coating. These two diffused semicircle loops on sprayed coatings are not clearly seen because of the reduced conductivity of the solution and scattered data.

The dimensions of semicircle loops in the Nyquist plot of the Ti coating were bigger, indicating that the anodic surface area of the coating was decreased by the formation of the protective oxide film rather than SS coating. The SS plate had higher resistance to the $\mathrm{H}_{2} \mathrm{SO}_{4}$-contaminated solution owing to the formation of the protective passive film [42].

The SS plate surface exhibited the protective passive film that is resistant to corrosion because the values of both $Z^{\prime}$ real and $-Z^{\prime \prime}{ }_{\text {imaginary }}$ axes are increased (Figure $5(\mathrm{a})$ ). From the initial to the prolonged exposure, the SS plate showed higher resistance to corrosion which can be attributed to the formation of compact and uniform passive layers [42].

On the other hand, the SS and Ti coatings showed less resistance to corrosion than the SS plate because of the formation of surface defects/cracks, which enhanced the corrosion rate due to penetration of aggressive solution. It can be seen from Figure 5(a) that the SS and Ti coatings exhibit diffused semicircle loops separated by two small loops.

The bigger loop shifted toward $Z^{\prime \prime}{ }_{\text {imaginary }}$ because of the formation of the capacitive passive film/corrosion products. The lower frequency loop shifted toward $Z^{\prime}$ real of the Nyquist plots (Figure 5(a)) because of the increased resistance to corrosion.

The nature of corrosion products/passive films plays a major role in controlling the corrosion of the sprayed samples at prolonged exposure [53]. In case of the SS plate and $\mathrm{Ti}$ coating, the passive film controls the corrosion of the samples. There is no role played by chemistry; rather, morphology controls the corrosion of samples.

The impedance values measured at lowest frequency $(0.01 \mathrm{~Hz})$ in Figure 5(b) were found to be the highest than those of $1 \mathrm{~h}$ of exposure to acidic $\mathrm{pH}$ solution for all samples. The impedance values of both sprayed coatings exhibited almost identical characteristics, but those of the $\mathrm{Ti}$ coatings were higher. This result is attributed to the fact that the $\mathrm{Ti}$ coating is more resistant to corrosion in the $\mathrm{H}_{2} \mathrm{SO}_{4}$ solution 
TABLE 1: Electrochemical parameters of the SS plate, SS-sprayed coating, and Ti-sprayed coating extracted after fitting of EIS data to suitable EECs with different exposure periods in $\mathrm{pH} 4$ solution.

\begin{tabular}{|c|c|c|c|c|c|c|}
\hline Time $(h)$ & & 1 & & & 312 & \\
\hline Sample ID & SS plate & SS sprayed & Ti sprayed & SS plate & SS sprayed & Ti sprayed \\
\hline$R_{\mathrm{s}}\left(\mathrm{k} \Omega \cdot \mathrm{cm}^{2}\right)$ & 6.77 & 5.20 & 8.64 & 5.02 & 5.37 & 8.45 \\
\hline$R \mathrm{p}\left(\mathrm{k} \Omega \cdot \mathrm{cm}^{2}\right)$ & 166.00 & 16.02 & 48.19 & 22.82 & 20.15 & 21.07 \\
\hline $\mathrm{CPE}_{1}$ & & & & & & \\
\hline$Q_{1}\left(1 \times 10^{-6}\right)\left(\Omega^{-1} \cdot \mathrm{cm}^{-2} \cdot \mathrm{s}^{n}\right)$ & 2.7 & 62.0 & 7.3 & 29.6 & 41.6 & 37.2 \\
\hline$n_{1}$ & 0.99 & 0.99 & 0.99 & 0.95 & 0.92 & 0.93 \\
\hline$C_{\text {eff1 }}\left(\mu \mathrm{F} \cdot \mathrm{cm}^{-2}\right)$ & 2.68 & 62.0 & 7.22 & 29.0 & 41.0 & 36.5 \\
\hline$R_{\mathrm{ct}}\left(\mathrm{k} \Omega \cdot \mathrm{cm}^{2}\right)$ & 11.87 & 9.15 & 10.97 & 350.02 & 11.56 & 46.33 \\
\hline $\mathrm{CPE}_{2}$ & & & & & & \\
\hline$Q_{2}\left(1 \times 10^{-6}\right)\left(\Omega^{-1} \cdot \mathrm{cm}^{-2} \cdot \mathrm{s}^{\mathrm{n}}\right)$ & 91.6 & 252.3 & 105.8 & 20.9 & 156.1 & 38.5 \\
\hline$n_{2}$ & 0.75 & 0.44 & 0.54 & 0.91 & 0.46 & 0.60 \\
\hline$C_{\text {eff } 2}\left(\mu \mathrm{F} \cdot \mathrm{cm}^{-2}\right)$ & 94.19 & 731.72 & 120.11 & 25.44 & 312.13 & 56.62 \\
\hline$W\left(1 \times 10^{-6}\right)\left(\Omega \cdot \mathrm{cm}^{2} \cdot \mathrm{s}^{-0.5}\right)$ & - & - & - & 4.2 & - & - \\
\hline
\end{tabular}

at $\mathrm{pH} 4$ after $312 \mathrm{~h}$ of exposure $[45,54-56]$. The Ti and SS coatings exhibited higher resistance at the highest studied frequency due to formation of passive films and deposition of corrosion products in defects/pores, respectively, and showed higher impedance.

After $312 \mathrm{~h}$ of exposure, the corrosion of SS and $\mathrm{Ti}$ coatings in acidic solution was controlled by their respective corrosion products and passive film [53]. The impedance value of Ti coating was greater than that of the SS-sprayed coating owing to the more stable and adherent passive oxide film formed on its surface after exposure to the solution. The SS plate had the highest impedance values compared to the sprayed coatings.

The phase shift $\theta\left(^{\circ}\right)-\log f(\mathrm{~Hz})$ Bode plots of samples after $312 \mathrm{~h}$ of exposure to solution are shown in Figure $5(\mathrm{~b})$. The scattered data shown in the middle frequency range are attributed due to the defective/porous oxide film caused by the corrosion products of SS and Ti coatings.

The shifting of the phase angle maxima toward $-75^{\circ}$ for the SS plate was attributed to the formation of the homogeneous passive film on the surface, which revealed the strengthening of the film in the solution. This result indicates that the passive film/corrosion products formed on the plate are surface resisted to the attack of corrosive ions [57].

The impedance data were validated by Kramers-Kronig (K-K) transformation by transforming the real axis into the imaginary axis and vice versa. The $\mathrm{K}-\mathrm{K}$ transformations are shown in Figure S2 and have been described elsewhere [58-60]. These results confirm the agreement between the experimental data and $\mathrm{K}-\mathrm{K}$ transformations, which is accordance with the linear system theory.

Brug's formula has been widely used to extract effective capacitance values from CPE parameters for studies on double layers [61]. Brug et al. [62] have established the relationship between $\mathrm{CPE}$ parameters and effective capacitance $\left(C_{\text {eff }}\right)$ associated with the CPE which can therefore be expressed as follows:

$$
C_{\text {eff }}=\frac{Q 1}{n} R^{(1-n) / n},
$$

where $Q$ is the CPE parameter such as nonideal double-layer capacitance, $R$ is a resistance caused by dissolution of the metal or alloy at the metal/solution interface in low frequency, and $n$ is the CPE exponent $(-1<n<1)$. When $n$ is $\sim 1,0.5,0$, and -1 , the CPE is equivalent to a capacitor, the Warburg diffusion, a resistor, and an inductor, respectively.

After fitting of EIS data to a suitable EEC, the electrochemical parameters are shown in Table 1 . The $R_{\mathrm{s}}$ is very high for all systems due to low conductively of the solution. The $R_{\mathrm{s}}$ is gradually decreased with increasing exposure periods due to involvement of more ions after reaction of metals in acidic $\mathrm{pH}$ solution [53].

The $R_{\mathrm{p}}$ and $R_{\mathrm{ct}}$ values of samples are gradually decreased and increased, respectively, as exposure periods increased. The $R_{\mathrm{p}}$ is emphasizing due to resistance caused by inhomogeneity of the metal surface, and it is decreased due to corrosion. The $R_{\mathrm{ct}}$ is increased for SS plate and Ti-sprayed coating due to protective nature of passive film while SS sprayed coating owing to deposition of corrosion products on surface. The corrosion products and passive oxide film increase their thickness as exposure periods were increased, resulting in high $R_{\mathrm{ct}}$ than $1 \mathrm{~h}$ of exposure [63]. The capacitance of the metal/coating surface and passive film/ corrosion products is derived as $C_{\text {eff1 }}$ and $C_{\text {eff2 }}$, respectively. The $C_{\text {eff1 }}$ is dramatically increased as $R_{\mathrm{p}}$ is decreased with exposure periods, which indicates that the metal/coating surface started to corrode, but as the $R_{\mathrm{ct}}$ is increased, $C_{\mathrm{eff} 2}$ is decreased. The $C_{\text {eff } 2}$ result was attributed to that the surface became homogenized due to formation of the passive layer or corrosion products on the metal/coating interface after $312 \mathrm{~h}$ of exposure. However, it is found that the $C_{\text {eff }}$ is greater for SS coating than the Ti coating and SS plate in all exposure periods. It indicates that the SS coating is more inhomogeneous and defective than other samples. The thickening of the oxide film was attributed to anodic oxidation and formation of the protective passive film/corrosion products that reduced the penetration of aggressive ions [64]. The corrosion product itself caused resistance to corrosion due to uniform and adherent deposition.

After $312 \mathrm{~h}$ of exposure, W was observed for the SS plate, possibly resulting from diffusion of the protective passive layer on the surface $[65,66]$. As exposure periods are increased, the passive film strength also increased. 


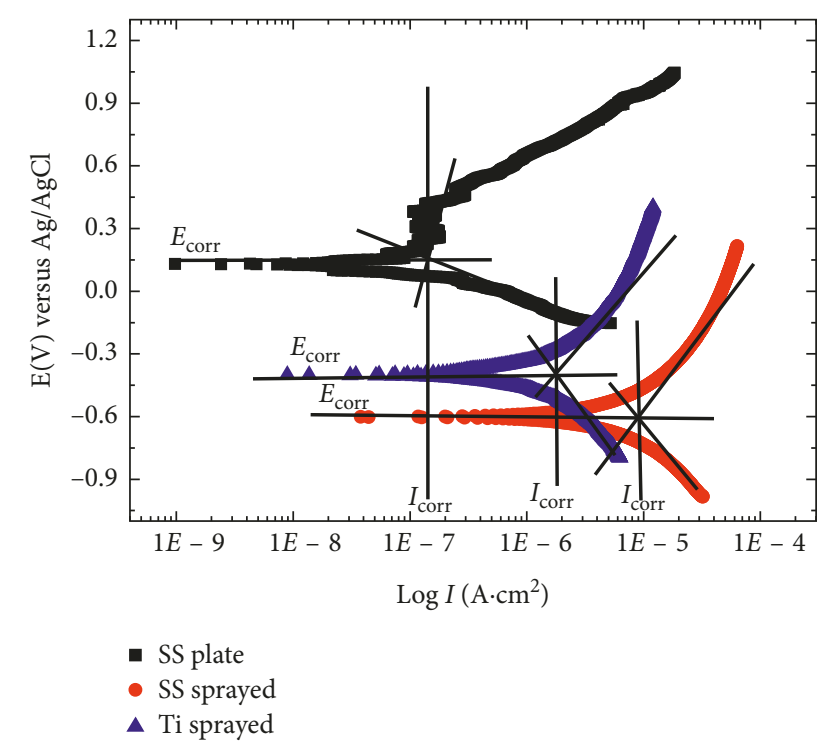

FIGURe 6: Potentiodynamic plots of the SS plate and sprayed coatings in $\mathrm{pH} 4$ solution after $312 \mathrm{~h}$ of exposure $(1 \mathrm{mV} / \mathrm{s})$.

After $1 \mathrm{~h}$ of exposure, $R_{\mathrm{p}}$ is found to be highest for all samples due to a barrier type of protection exhibited by the coatings. The $\mathrm{NiO}, \mathrm{Fe}_{2} \mathrm{O}_{3}, \mathrm{FeO}$, and $\mathrm{Cr}_{2} \mathrm{O}_{3}$ thin films are formed on the SS plate [42] which give the protection against corrosion. Initially, the metal or coating surface does not start to react with solution resulting in high $R_{\mathrm{p}}$, but once proper reaction has occurred, the surfaces start to corrode. At the time of corrosion initiation, $R_{\mathrm{ct}}$ will involve which causes resistance to penetration of the solution toward the metal surface. Therefore, $R_{\mathrm{p}}$ is decreased and $R_{\mathrm{ct}}$ is increased as exposure periods are increased. The film formed on the surfaces was imperfect and rough $[67,68]$ after $1 \mathrm{~h}$ of exposure; thus, the dispersion coefficient $(n)$ is less for CPE2. As the exposure periods were increased, the $R_{\mathrm{ct}}$ values increased and CPE decreased for passive layer/corrosion products of the samples. $R_{\mathrm{ct}}$ is high for all samples due to deposition of corrosion products on SS-sprayed coating and the protective passive layer on Ti-sprayed coatings and the SS plate after $312 \mathrm{~h}$ of exposure.

3.4.2. Potentiodynamic Studies. Potentiodynamic studies were carried out after $312 \mathrm{~h}$ of exposure, and results are shown in Figure 6. The SS plate showed pitting and many breakdown potentials during anodic scanning. The breakdown potentials may be caused by oxidation of the metal surface due to impressed current which form a new phase or a metastable passive film, that altered the passive film properties [69]. Therefore, there is a chance that another oxide phase could form on the surface, which might be protective in nature.

The current density of the SS plate is lower than that of Ti and SS coatings during anodic scanning. The interesting observation is found in case of Ti and SS coatings that there is a gradual increase in anodic current density during anodic scanning. It may be due to corrosion or transformation of unstable oxide films of these samples, and whatever corrosion products/passive film formed was deposited on the surface.
The anodic and passive corrosion current of the $\mathrm{Ti}$ coating was lower than that of the SS coating, which means that, in this case, the former is more likely to form compact, protective, and adherent passive oxide films [70,71].

The passive film of Ti-sprayed coating resisted the penetration of corrosive species of the solution; thus, the reducing corrosion rate is observed. During cathodic scanning, all samples exhibited hydrogen evolution reaction which dominated over the oxygen reduction reaction [72].

The electrochemical parameters were extracted after fitting of potentiodynamic plots to the Tafel region using the Stern-Geary equation

$$
I_{\text {corr }}=\frac{B}{R_{\text {total }}} \text {. }
$$

The Stern-Geary constant $(B)$ can be calculated by putting the values for corrosion current density $\left(I_{\text {corr }}\right)$ and total polarization resistance $\left(R_{\text {total }}\right)$ in $(2)$. The extracted data on the corrosion potential $\left(E_{\text {corr }}\right), I_{\text {corr }}, R_{\text {total }}, B$, and the corrosion rate of samples after $312 \mathrm{~h}$ of exposure to $\mathrm{pH} 4$ solution are shown in Table 2.

The $E_{\text {corr }}$ of the SS plate and SS and Ti coatings are 0.138 , -0.594 , and $-0.403 \mathrm{~V}$ versus $\mathrm{Ag} / \mathrm{AgCl}$, respectively. The SS plate exhibited nobler $E_{\text {corr }}$ than the Ti coating followed by the SS coating.

The nobler potential of the SS plate is due to formation of the Cr-enriched oxide film, whereas others exhibited the active potential. The active $E_{\text {corr }}$ of SS- and Ti-sprayed coatings compared to the SS plate is attributed to the presence of defects on the coating surface.

Lai et al. observed that when SS was exposed to $\mathrm{H}_{2} \mathrm{SO}_{4}$ contaminated water solution, it formed $\mathrm{NiO}, \mathrm{Fe}_{2} \mathrm{O}_{3}, \mathrm{FeO}$, and $\mathrm{Cr}_{2} \mathrm{O}_{3}$ thin films which were protective in nature and noble [42]. The active potential of SS coating was due to the presence of defective or porous oxide/corrosion films that made the sample more susceptible to corrosion and exhibit the mixed potential [73].

The studied $\mathrm{pH}$ solution was acidic and led to the deterioration of the samples. During exposure, the formed corrosion products deposited on the sample surface. The corrosion products blocked the defects/pores of the samples and resisted the penetration of the solution $[74,75]$.

The iron oxides were more active and therefore exhibited the active potential. The Ti coating exhibited a nobler potential than SS coating because it had only fine and elongated cracks (Figure 2(c)), which stifled the aggressive species of the solution from reaching the base metal. In contrast, the SS coating contains many connected pores and valley morphology where the acidic solution can accumulate and induce crevice corrosion.

These results indicate that the passive film formed on the Ti-sprayed coating after exposure to $\mathrm{pH} 4$ solution is protective, nonporous, compact, and resistant to the penetration of aggressive ions in the solution. The SS coating has porous and nonprotective corrosion products/iron oxides.

The $R_{\text {total }}$ values of the SS plate, SS-sprayed coating, and Ti-sprayed coating are $379.860,33.792$, and $68.464 \mathrm{k} \Omega \cdot \mathrm{cm}^{2}$, respectively. The higher $R_{\text {total }}$ value of Ti coating compared to the SS coating suggests that it can be used as a coating to 
TABLE 2: Electrochemical parameters extracted after fitting of potentiodynamic plots to the Tafel region.

\begin{tabular}{lccccc}
\hline \multirow{2}{*}{ Sample ID } & \multicolumn{3}{c}{ Electrochemical parameters } \\
& $E_{\text {corr }}(\mathrm{V})$ versus $\mathrm{Ag} / \mathrm{AgCl}$ & $I_{\text {corr }}\left(\mu \mathrm{A} \cdot \mathrm{cm}^{-2}\right)$ & $R_{\text {total }}\left(\mathrm{k} \Omega \cdot \mathrm{cm}^{2}\right)$ & $B(\mathrm{~V})$ & Corrosion rate $\left(\mu \mathrm{m} \cdot \mathrm{y}^{-1}\right)$ \\
\hline SS plate & 0.138 & 0.382 & 379.860 & 0.15 & 5.132 \\
SS sprayed & -0.594 & 19.803 & 33.792 & 0.67 & 266.043 \\
Ti sprayed & -0.403 & 1.913 & 68.464 & 0.13 & 42.703 \\
\hline
\end{tabular}

protect the materials in $\mathrm{H}_{2} \mathrm{SO}_{4}$-contaminated water solution, even at low $\mathrm{pH}$. The B values were calculated by using (2), and it was found that the SS plate and Ti-sprayed coating were identical and less active, while SS-sprayed coating showed $0.67 \mathrm{~V}$ which is more pronounced to corrosion [76]. The $\mathrm{B}$ value of the SS plate and Ti-sprayed coating is under the active control, while the SS-sprayed surface exhibits active dissolution values which influence the corrosion phenomena. The calculated $I_{\text {corr }}$ value of SS-sprayed samples reveals the activeness of coating, while the SS plate and Ti-sprayed coating control the corrosion process in acidic solution at longer duration of exposure.

The corrosion rate $\left(\mu \mathrm{m} \cdot \mathrm{y}^{-1}\right)$ was calculated by the following equation [77]:

Corrosion rate $\left(\mu \mathrm{m} \cdot \mathrm{y}^{-1}\right)=\frac{3.27 \times I_{\text {corr }} \times \mathrm{EW}}{d}$.

The corrosion rate in (3) is expressed in micrometres per year $(\mu \mathrm{m} /$ year $)$ and $I_{\text {corr }}$ in $\mu \mathrm{A} \cdot \mathrm{cm}^{-2}$. The $I_{\text {corr }}$ was obtained by dividing the total surface area of the working electrode under the corrosion current $(\mu \mathrm{A})$. EW represents the equivalent weight $\left(\mathrm{g} \cdot \mathrm{mol}^{-1}\right)$, and $d$ is the density $\left(\mathrm{g} \cdot \mathrm{cm}^{-3}\right)$.

The corrosion rate of the SS coating is $266.043 \mu \mathrm{m} \cdot \mathrm{y}^{-1}$ and is greater than that of the SS plate and Ti coating by 51 . 84 and 6.23 times, respectively. This result indicates that the SS is not an effective coating material for deposition by the arc thermal spray process in $\mathrm{pH} 4$ solution and long duration of exposure.

The corrosion rate data of the SS coating revealed that it totally dissolved/corroded down to the base substrate. The initial coating thickness was $200 \mu \mathrm{m}$, while the corrosion rate was $266.043 \mu \mathrm{m} \cdot \mathrm{y}^{-1}$. Thus, it may be reported that the $\mathrm{Ti}$ coating was effective in protecting the surface than the SS coating. The Ti can be used as a coating material to protect the waste water reservoir and extend its service life.

3.4.3. Characterization of Corrosion Products after Potentiodynamic Studies in $\mathrm{pH} 4$ by Different Techniques. The morphology of corrosion products was examined by SEM, and results are shown in Figure 7. On the SS plate surface, the passive film was adherent, uniform, and regularly deposited, thus preventing the penetration of solution (Figure 7(a)). The edges of the surface show few cracks caused by the destructive potentiodynamic experiment, and the passive film prevented the cracking. After potentiodynamic studies, the SS plate surface did not show any other type of corrosion products/rust.

The SS coating exhibited different sizes of corrosion product morphology with micropore formation (Figure $7(b)$ ). The net-like microstructure of corrosion products is attributed to the presence of porous iron oxides. Through the net and thread morphologies, the acidic solution easily penetrated the substrate and formed corrosion products.

The morphology of corrosion products formed on the $\mathrm{Ti}$ coating was totally different from that on the SS plate and sprayed coating. The passive films formed on the Ti-sprayed surface exhibit microcracks, plate, and globular morphology (Figure 7(c)). The globular particles block the micro- and macrocracks on the top surface. Therefore, enhanced corrosion resistance was observed after $312 \mathrm{~h}$ of exposure than on SS-sprayed coating.

Passive oxide films of Ti coating contain plate-like microstructures that were uniformly deposited on the surface. Similar morphologies were not observed in the corrosion products of the SS plate and sprayed coating.

The phases present in the corrosion products of all samples after potentiodynamic studies were studied by XRD. The identification of phases in corrosion products is shown in Figure 8. The SS plate exhibits the presence of tetrataenite $(\mathrm{FeNi})$ and $\mathrm{Fe}$. It is reported that $\mathrm{FeNi}$ is unstable and can deteriorate into other forms, if it exposes for long term to low-temperature environments [78].

The presence of lepidocrocite $(\gamma-\mathrm{FeOOH})$ in the corrosion products of SS-sprayed coatings confirmed that this coating was susceptible to corrosion in acidic solution. However, $\mathrm{Ti}$ coating exhibits composite oxides along with $\mathrm{Ti}$ and $\mathrm{TiO}$. Therefore, the improved corrosion resistance of Ti-sprayed coating is observed by formation of $\mathrm{TiO}_{2}$ (rutile and anatase), and this observation corroborates with EIS and potentiodynamic results. The passive oxides of Ti such as $\mathrm{TiO}_{2}$ and $\mathrm{Ti}_{3} \mathrm{O}_{5}$ have formed. The $\mathrm{TiO}_{2}$ is thermodynamically more stable than others [79]. Therefore, the Ti-sprayed coating is attributed to improved corrosion resistance properties of coating in $\mathrm{H}_{2} \mathrm{SO}_{4}$ solution. The transformation of Ti into $\mathrm{TiO}_{2}$ in the $\mathrm{H}_{2} \mathrm{SO}_{4}$ environment is well documented elsewhere $[80,81] . \mathrm{TiO}_{3}$ and some amount of $\mathrm{TiO}$ (Figure 3) may be transformed into $\mathrm{TiO}_{2}$ and $\mathrm{Ti}_{3} \mathrm{O}_{5}$ due to a strong oxidizing ability of $\mathrm{H}_{2} \mathrm{SO}_{4}$ solution. Thus, corrosion products/passive film of Ti-sprayed coating exhibits some peaks of TiO (Figure 8). Therefore, corrosion is observed after $312 \mathrm{~h}$ of exposure to $\mathrm{H}_{2} \mathrm{SO}_{4}$ solution. Once proper transformation of $\mathrm{Ti}$ and $\mathrm{TiO}$ into the stable form occurred, then the corrosion rate would be completely suppressed.

\section{Conclusions}

From the above results and discussion, the following can be concluded:

(1) The EIS and potentiodynamic studies revealed the protective properties of $\mathrm{Ti}$ coating due to formation 


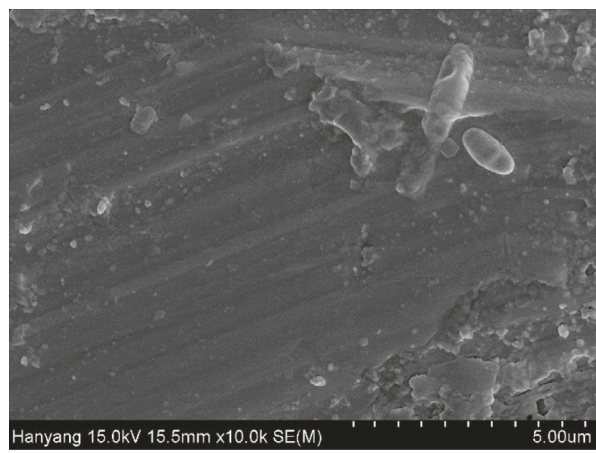

(a)

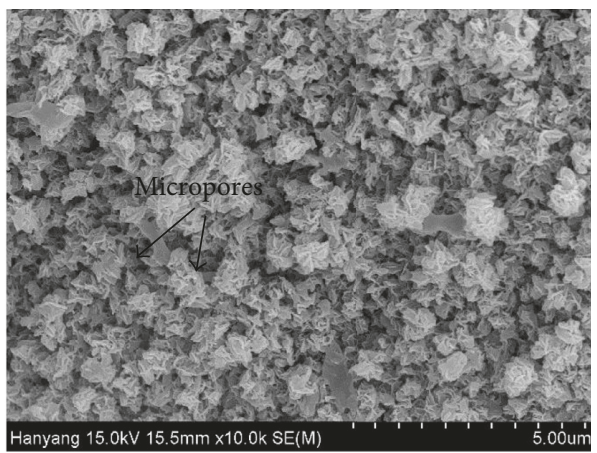

(b)

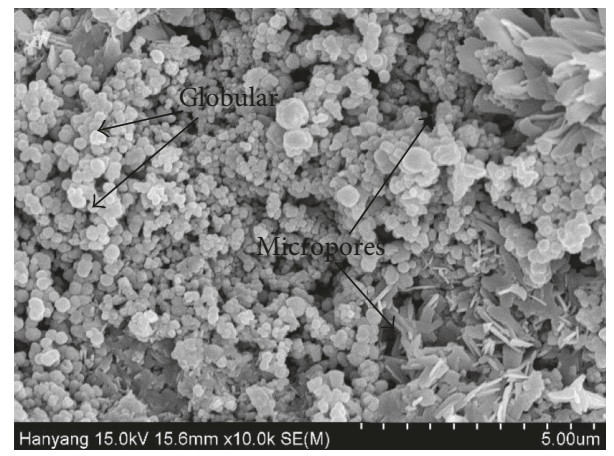

(b)

FIGURE 7: SEM images of corrosion products formed on the (a) SS plate, (b) SS-sprayed coating, and (c) Ti-sprayed coating after potentiodynamic studies in $\mathrm{pH} 4$ solution.

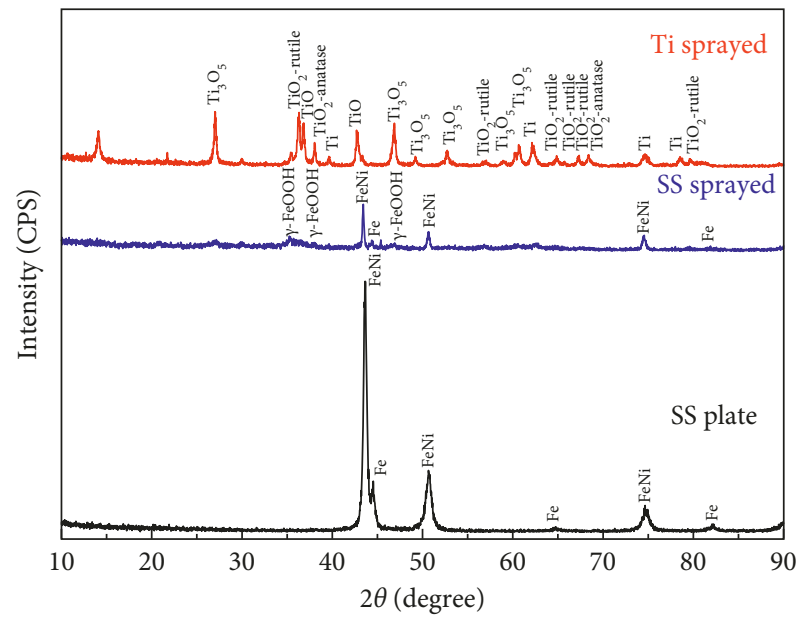

FIGURE 8: XRD of the SS plate and sprayed coatings after potentiodynamic studies in $\mathrm{pH} 4$ solution $\left(0.5^{\circ} / \mathrm{min}\right)$.

of the protective oxide film at longer duration of exposure to acidic solution.

(2) The improved corrosion resistance properties of Tisprayed coating than SS-sprayed coating after $312 \mathrm{~h}$ of exposure to acidic solution is attributed to transformation of unstable oxides into stable, protective, and adherent $\mathrm{TiO}_{2}$ (rutile and anatase) which is a thermodynamically stable oxide.

(3) Examination of the corrosion product morphology by SEM revealed the compact, globular, and crystalline corrosion products/oxide films on the Ti sample, while the SS sample formed defective and microcrackbearing corrosion products.

(4) The SS plate showed uniform, crack-free passive films, with no trace of corrosion products after $312 \mathrm{~h}$ of exposure to acidic solution.

\section{Conflicts of Interest}

The authors declare no conflicts of interest.

\section{Authors' Contributions}

Jitendra Kumar Singh and Jin-ho Park conducted the experiments and wrote the initial draft of the manuscript. HanSeung Lee designed the experiments. Jitendra Kumar Singh and Han-Seung Lee analyzed the data and wrote the final manuscript. Han-Seung Lee, Mohamed A. Ismail, and Jitendra Kumar Singh reviewed and contributed to the final revised manuscript. All authors contributed to the analysis of the data and read the final paper.

\section{Acknowledgments}

This research was supported by the Korea Ministry of Environment (MOE) as Public Technology Program based on Environmental Policy (no. 2015000700002) and Basic Science Research Program through the National Research Foundation of Korea (NRF) funded by the Ministry of Science, ICT and Future Planning (no. 2015R1A5A1037548) 


\section{Supplementary Materials}

Figure S1: Nyquist plots (at higher frequency ranges) of the SS plate and sprayed coatings in $\mathrm{pH} 4$ solution after $1 \mathrm{~h}$ of exposure $(100 \mathrm{kHz}$ to $40 \mathrm{kHz})$. Figure S2: Kramers-Kronig transformation of the EIS data obtained for the SS plate and sprayed coatings in $\mathrm{pH} 4$ solution after (a) $1 \mathrm{~h}$ and (b) $312 \mathrm{~h}$ $(100 \mathrm{kHz}$ to $0.01 \mathrm{~Hz})$. (Supplementary Materials)

\section{References}

[1] H. S. Jensen, P. N. L. Lens, J. L. Nielsen et al., "Growth kinetics of hydrogen sulfide oxidizing bacteria in corroded concrete from sewers," Journal of Hazardous Materials, vol. 189, no. 3, pp. 685-691, 2011.

[2] M. Lupsea, L. Tiruta-Barna, and N. Schiopu, "Leaching of hazardous substances from a composite construction product-An experimental and modelling approach for fibre-cement sheets," Journal of Hazardous Materials, vol. 264, pp. 236-245, 2014.

[3] Q. Guo, "Increases of lead and chromium in drinking water from using cement-mortar-lined pipes: initial modelling and assessment," Journal of Hazardous Materials, vol. 56, no. 1-2, pp. 181-213, 1997.

[4] E. Owaki, R. Okamoto, and D. Nagashio, "Deterioration of concrete in an advanced water treatment plant," in Concrete under Severe Condition: Environment and Loading, E. Gjorv, E. Odd, K. Sakai, and N. Banthia, Eds., E \& F N Spon, London, UK, 1998.

[5] R. N. Swamy and S. Tanikawa, "An external surface coating to protect concrete and steel from aggressive environments," Materials and Structures, vol. 26, no. 8, pp. 465-478, 1993.

[6] D. Crowe and R. Nixon, "Corrosion of stainless steels in waste water applications," 2016, http://www.hwea.org/wp-content/ uploads/2015/07/150204_Corrosion_of_Stainless_Steels_in_ Wastewater_Applications.pdf.

[7] B. B. Bhalerao and S. J. Arceivala, "Application of corrosion control techniques in municipal water and waste water engineering," 2016, http://eprints.nmlindia.org/5825/1/129-139.PDF.

[8] "Alkalinity profiling in wastewater operations, ops challenge laboratory event 2015," 2017, http://www.rmwea.org/docs/ Alkalinity_Profiling_in_Wastewater_Operations_White_Paper_ OPS_2015_ED_1.20.15.pdf.

[9] V. Kumar, "Protection of steel reinforcement for concrete: a review," Corrosion Reviews, vol. 16, no. 4, pp. 317-358, 1998.

[10] A. I. Fernández-Abia, J. Barreiro, D. González-Madruga, and L. N. López de Lacalle, "Effect of mechanical pre-treatments in the behavior of nanostructured PVD-coated tools in turning," International Journal of Advanced Manufacturing Technology, vol. 73, no. 5-8, pp. 1119-1132, 2014.

[11] S. Rodríguez-Barrero, J. Fernández-Larrinoa, I. Azkona, L. N. López de Lacalle, and R. Polvorosa, "Enhanced performance of nanostructured coatings for drilling by droplet elimination," Materials and Manufacturing Processes, vol. 31, no. 5, pp. 593-602, 2016.

[12] L. Pawlowski, The Science and Engineering of Thermal Spray Coatings, John Wiley \& Sons Ltd., West Sussex, UK, 2nd edition, 2008.

[13] G. Jandin, H. Liao, Z. Q. Feng, and C. Coddet, "Correlations between operating conditions, microstructure and mechanical properties of twin wire arc sprayed steel coatings," $M a-$ terials Science and Engineering: A, vol. 349, no. 1-2, pp. 298-305, 2003.

[14] H. S. Lee, J. K. Singh, M. A. Ismail, and C. Bhattacharya, "Corrosion resistance properties of aluminum coating applied by arc thermal metal spray in SAE J2334 solution with exposure periods," Metals, vol. 6, no. 3, pp. 1-15, 2016.

[15] H. S. Lee, J. K. Singh, and J. H. Park, "Pore blocking characteristics of corrosion products formed on aluminum coating produced by arc thermal metal spray process in $3.5 \mathrm{wt} . \% \mathrm{NaCl}$ solution," Construction and Building Materials, vol. 113, pp. 905-916, 2016.

[16] H. S. Lee, J. H. Park, J. K. Singh, and M. A. Ismail, "Protection of reinforced concrete structures of waste water treatment reservoirs with stainless steel coating using arc thermal spraying technique in acidified water," Materials, vol. 9, no. 9, pp. 1-20, 2016.

[17] H. B. Choe, H. S. Lee, and J. H. Shin, "Experimental study on the electrochemical anti corrosion properties of steel structures applying the arc thermal metal spraying method," Material, vol. 7, no. 12, pp. 7722-7736, 2014.

[18] A. Guenbour, A. Benbachir, and A. Kacemi, "Evaluation of the corrosion performance of zinc-phosphate-painted carbon steel," Surface and Coatings Technology, vol. 113, no. 1-2, pp. 36-43, 1999.

[19] N. Cinca, C. R. C. Lima, and J. M. Guilemany, "An overview of intermetallics research and application: status of thermal spray coatings," Journal of Materials Research and Technology, vol. 2, no. 1, pp. 75-86, 2013.

[20] D. F. Bettridge and R. G. Ubank, "Quality control of hightemperature protective coatings," Materials Science and Technology, vol. 2, no. 3, pp. 232-242, 1986.

[21] H. D. Steffens, Z. Babiak, and M. Wewel, "Recent developments in arc spraying," IEEE Transactions on Plasma Science, vol. 18, pp. 974-975, 1990.

[22] H. A. M. Muhamad, S. N. Hayati, A. S. Kiyai, and M. S. N. Binti, "Critical process and performance parameter of thermal arc spray coatings," International Journal of Materials Engineering Innovation, vol. 5, no. 1, pp. 12-27, 2014.

[23] J. R. Davis, Surface Engineering for Corrosion and Wear Resistance, ASM International, Geauga County, OH, USA, 2001.

[24] KS F4716, Cement Filling Compound for Surface Preparation, Korean Agency for Technology and Standards (KATS), Seoul, Korea, 2001.

[25] S. Shrestha and A. J. Sturgeon, "Use of advanced thermal spray processes for corrosion protection in marine environments," Surface Engineering, vol. 20, no. 4, pp. 237-243, 2004.

[26] L. Wang and J. Sun, "Molybdenum modified AISI 304 stainless steel bipolar plate for proton exchange membrane fuel cell," Journal of Renewable and Sustainable Energy, vol. 5, no. 2, p. 021407, 2013.

[27] M. Dadfar, M. H. Fathi, F. Karimzadeh, M. R. Dadfar, and A. Saatchi, "Effect of TIG welding on corrosion behavior of 316L stainless steel," Materials Letters, vol. 61, no. 11-12, pp. 2343-2346, 2007.

[28] J. Liu, F. Chen, Y. Chen, and D. Zhang, "Plasma nitrided titanium as a bipolar plate for proton exchange membrane fuel cell," Journal of Power Sources, vol. 187, no. 2, pp. 500$504,2009$.

[29] X. Cheng and S. G. Roscae, "Corrosion behaviour of titanium in the presence of calcium phosphate and serum proteins," Biomaterials, vol. 26, no. 35, pp. 7350-7356, 2005.

[30] J. Pouilleau, D. Devilliers, F. Garrido, S. Durand-Vidal, and E. Mahe, "Structure and composition of passive titanium oxide film," Materials Science and Engineering: B, vol. 47, no. 3, pp. 235-243, 1997.

[31] S. Kumar, T. S. N. Narayanan, S. G. Raman, and S. K. Seshadri, "Thermal oxidation of cp-Ti: evaluation of characteristics and corrosion resistance as a function of treatment time," 
Materials Science and Engineering: C, vol. 29, no. 6, pp. 1942-1949, 2009.

[32] J. E. Sundgren, P. Bodo, and I. Lundstrom, "Auger electron microscopic studies of the interface between human tissue and implants of titanium and stainless steel," Journal of Colloid and Interface Science, vol. 110, no. 1, pp. 9-20, 1984.

[33] C. J. Goodacre, G. Bernal, K. Rungcharassaeng, and J. Y. Kan, "Clinical complications with implant and implant prosthesis," Journal of Prosthetic Dentistry, vol. 90, no. 2, pp. 121-132, 2003.

[34] S. Gudic, J. Radosevic, and M. Kliskic, "Study of passivation of $\mathrm{Al}$ and Al-Sn alloys in borate buffer solution using electrochemical impedance spectroscopy," Electrochimica Acta, vol. 47, no. 18, pp. 3009-3016, 2002.

[35] F. J. Martin, G. T. Cheek, W. E. O'Grady, and P. M. Natishan, "Impedance studies of the passive film on aluminium," Corrosion Science, vol. 47, no. 12, pp. 3187-3201, 2005.

[36] Y. J. Liu, Z. Y. Wang, and W. Ke, "Study on influence of native oxide and corrosion products on atmospheric corrosion of pure Al," Corrosion Science, vol. 80, pp. 169-176, 2014.

[37] V. Maurice, W. P. Yang, and P. Marcus, "XPS and STM study of passive films formed on Fe-22Cr (110) single-crystal surfaces," Journal of The Electrochemical Society, vol. 143, no. 4, pp. 1182-1200, 1996.

[38] A. Goossens and D. D. Macdonald, "A photoelectrochemical impedance spectroscopic study of passive tungsten," Journal of Electroanalytical Chemistry, vol. 352, no. 1-2, pp. 65-81, 1993.

[39] D. D. Macdonald, E. Sikora, and G. Engelhardt, "Characterizing electrochemical systems in the frequency domain," Electrochimica Acta, vol. 43, no. 1-2, pp. 87-107, 1998.

[40] H. Song and D. D. Macdonald, "Photoelectrochemical impedance spectroscopy I. Validation of the transfer function by Kramers-Kronig transformation," Journal of The Electrochemical Society, vol. 138, no. 5, pp. 1408-1410, 1991.

[41] A. Baron, W. Simka, and W. Chrzanowski, "EIS tests of electrochemical behaviour of Ti6Al4V and Ti6Al7Nb alloys," JAMME, vol. 21, pp. 23-26, 2007.

[42] W. Y. Lai, W. Z. Zhao, Z. F. Yin, and J. Zhang, "EIS and XPS studies on passive film of AISI 304 stainless steel in dilute sulfuric acid solution," Surface and Interface Analysis, vol. 44, no. 4, pp. 418-425, 2012.

[43] R. T. Loto, "Pitting corrosion evaluation of austenitic stainless steel type 304 in acid chloride media," Journal of Materials and Environmental Science, vol. 4, pp. 448-459, 2013.

[44] V. Mitrovic-Scepanovic and R. J. Brigham, "The localized corrosion of stainless steel in high purity sulphate solutions," Corrosion Science, vol. 27, no. 6, pp. 545-553, 1987.

[45] A. Fattah-alhosseini and S. Vafaeian, "Passivation behavior of a ferritic stainless steel in concentrated alkaline solutions," Journal of Materials Research and Technology, vol. 4, no. 4, pp. 423-428, 2015.

[46] J. B. Wen, J. L. Ma, and J. G. He, Al-Base Sacrificial Anode Material for Corrosion Protection, Chemical Industry Press, Beijing, China, 2012.

[47] C. Liu, Q. Bi, and A. Matthews, "EIS comparison, performance of PVD TiN and CrN coated mild steel in $0.5 \mathrm{~N} \mathrm{NaCl}$ aqueous solution,” Corros. Sci, vol. 43, pp. 1953-1961, 2001.

[48] O. de Rincon, A. Rincon, M. Sanchez et al., "Evaluating Zn, Al and Al-Zn coatings on carbon steel in a special atmosphere," Construction and Building Materials, vol. 23, no. 3, pp. 1465-1471, 2009.

[49] M. M. Verdian, K. Raeissi, and M. Salehi, "Corrosion performance of HVOF and APS thermally sprayed NiTi intermetallic coatings in $3.5 \% \mathrm{NaCl}$ solution," Corrosion Science, vol. 52, no. 3, pp. 1052-1059, 2010.

[50] D. Yang, C. Liu, X. Liu, M. Qi, and G. Lin, "EIS diagnosis on the corrosion behavior of TiN coated NiTi surgical alloy," Current Applied Physics, vol. 5, no. 5, pp. 417-421, 2005.

[51] Y. C. Xin, J. Jiang, K. F. Huo, G. Y. Tang, X. B. Tian, and P. K. Chu, "Corrosion resistance and cytocompatibility of biodegradable surgical magnesium alloy coated with hydrogenated amorphous silicon," Journal of Biomedical Materials Research Part A, vol. 89, no. 3, pp. 717-726, 2009.

[52] H. Y. Ha and T. H. Lee, "Determining factors for the protectiveness of the passive film of FeCrN stainless steel formed in sulfuric acid solutions," Corrosion Science and Technology, vol. 12, no. 4, pp. 163-170, 2013.

[53] J. K. Singh and D. D. N. Singh, "The nature of rusts and corrosion characteristics of low alloy and plain carbon steels in three kinds of concrete pore solution with salinity and different pH," Corrosion Science, vol. 56, pp. 129-142, 2012.

[54] C. Boissy, C. Alemany-Dumont, and B. Normand, "EIS evaluation of steady-state characteristic of 316L stainless steel passive film grown in acidic solution," Electrochemistry Communications, vol. 26, pp. 10-12, 2013.

[55] T. Balusamy, M. Jamesh, S. Kumar, and T. S. N. Sankara Narayanan, "Corrosion resistant Ti alloy for sulphuric acid medium: suitability of Ti-Mo alloys," Materials and Corrosion, vol. 63, pp. 803-806, 2012.

[56] T. P. Cheng, J. T. Lee, and W. T. SAI, "Passivation of titanium in molybdate-containing sulphuric acid solution," Electrochimica Acta, vol. 36, no. 14, pp. 2069-2076, 1991.

[57] H. Luo, C. Dong, K. Xiao, and X. Li, "The passive behaviour of ferritic stainless steel containing alloyed tin in acidic media," RSC Advances, vol. 6, no. 12, pp. 9940-9449, 2016.

[58] A. Fattah-alhosseini and S. Vafaeian, "Influence of grain refinement on the electrochemical behavior of AISI, 430 ferritic stainless steel in an alkaline solution," Applied Surface Science, vol. 360, pp. 921-928, 2016.

[59] A. Fattah-alhosseini, H. Elmkhah, and F. R. Attarzadeh, "On the electrochemical behavior of PVD Ti-coated AISI 304 stainless steel in borate buffer solution," Journal of Materials Engineering and Performance, vol. 26, no. 4, pp. 1792-1800, 2017.

[60] B. A. Boukamp, "Practical application of the Kramers-Kronig transformation on impedance measurements in solid state electrochemistry," Solid State Ionics, vol. 62, no. 1-2, pp. 131-141, 1993.

[61] B. Hirschorn, M. E. Orazem, B. Tribollet, V. Vivier, I. Frateur, and M. Musiani, "Determination of effective capacitance and film thickness from constant-phase-element parameters," Electrochimica Acta, vol. 55, no. 21, pp. 6218-6227, 2010.

[62] G. J. Brug, A. L. G. van den Eeden, M. Sluyters-Rehbach, and J. H. Sluyters, "The analysis of electrode impedances complicated by the presence of a constant phase element," Journal of Electroanalytical Chemistry and Interfacial Electrochemistry, vol. 176, no. 1-2, pp. 275-295, 1984.

[63] E. O. Mayne and C. L. Page, "Green corrosion inhibitor: theory and practice," British Corrosion Journal, vol. 7, p. 115, 1972.

[64] M. Nagayama and S. Kawamura, "Anodic oxidation of ferrous ion on passive iron," Electrochimica Acta, vol. 12, no. 8, pp. 1109-1119, 1967.

[65] Q. Mohsen and S. A. Fadl-Allah, "Improvement in corrosion resistance of commercial pure titanium for the enhancement of its biocompatibility," Materials and Corrosion, vol. 62, no. 4, pp. 310-319, 2011. 
[66] Q. G. Jiang, Q. Miao, W. P. Liang et al., "Corrosion behavior of arc sprayed Al-Zn-Si-RE coatings on mild steel in $3.5 \mathrm{wt} . \%$ NaCl solution," Electrochimica Acta, vol. 115, pp. 644-656, 2014.

[67] B. Cox and Y. M. Wong, "Simulating porous oxide films on zirconium alloys," Journal of Nuclear Materials, vol. 218, no. 3, pp. 324-334, 1995.

[68] A. Al-Negheimish, A. Alhozaimy, R. R. Hussain, R. Al-Zaid, J. K. Singh, and D. D. N. Singh, "Role of manganese sulfide inclusions in steel rebar in the formation and breakdown of passive films in concrete pore solutions," Corrosion, vol. 70, no. 1, pp. 74-86, 2014.

[69] W. Lai, W. Zhao, F. Wang, C. Qi, and J. Zhang, "EIS study on passive films of AISI 304 stainless steel in oxygenous sulfuric acid solution," Surface and Interface Analysis, vol. 41, no. 6, pp. 531-539, 2009.

[70] A. Singh, B. P. Singh, M. R. Wani, D. Kumar, J. K. Singh, and V. Singh, "Effect of anodization on corrosion behaviour and biocompatibility of Cp-titanium in simulated body fluid," Bulletin of Materials Science, vol. 36, no. 5, pp. 931-937, 2013.

[71] M. Jamesh, T. S. N. Sankara Narayanan, and P. K. Chu, "Thermal oxidation of titanium: evaluation of corrosion resistance as a function of cooling rate," Materials Chemistry and Physics, vol. 138, no. 2-3, pp. 565-572, 2013.

[72] B. Jegdic, D. M. Drazic, and J. P. Popic, "Corrosion potential of 304 stainless steel in sulfuric acid," Journal of the Serbian Chemical Society, vol. 71, no. 5, pp. 543-551, 2006.

[73] D. Dzhurinskiy, E. Maeva, E. Leshchinsky, and R. G. Maev, "Corrosion protection of light alloys using low pressure cold spray," Journal of Thermal Spray Technology, vol. 21, no. 2, pp. 304-313, 2012.

[74] A. Meroufel and S. Touzain, "EIS characterization of new zinc-rich powder coatings," Progress in Organic Coatings, vol. 59, no. 3, pp. 197-205, 2007.

[75] C. M. Abreu, M. Izquierdo, M. Keddam, X. R. Novoa, and H. Takenouti, "Electrochemical behavior of zinc-rich epoxy paints in $3 \% \mathrm{NaCl}$ solution," Electrochimica Acta, vol. 41, no. 15 , pp. 2405-2415, 1996.

[76] C. Andrade and J. A. Gonzalez, "Quantitative measurements of corrosion rate of reinforcing steels embedded in concrete using polarization resistance measurements," Materials and Corrosion, vol. 29, no. 8, pp. 515-519, 1978.

[77] S. W. Dean, "Electrochemical methods of corrosion testing," in Electrochemical Techniques for Corrosion, R. Baboian, Ed., NACE, Houston, TX, USA, 1977.

[78] Z. Wu, H. Bei, F. Otto, G. M. Pharr, and E. P. George, "Recovery, recrystallization, grain growth and phase stability of a family of FCC-structured multi-component equiatomic solid solution alloys," Intermetallics, vol. 46, pp. 131-140, 2014.

[79] R. Bansal, J. K. Singh, V. Singh, D. D. N. Singh, and P. Das, "Optimization of oxidation temperature for commercially pure titanium to achieve improved corrosion resistance," Journal of Materials Engineering and Performance, vol. 26, no. 3, pp. 969-977, 2017.

[80] Z. J. Liu, X. Zhong, J. Walton, and G. E. Thompson, “Anodic film growth of titanium oxide using the 3-electrode electrochemical technique: effects of oxygen evolution and morphological characterizations," Journal of The Electrochemical Society, vol. 163, no. 3, pp. E75-E82, 2016.

[81] M. A. Selimin, Z. Malik, N. Anjang, M. I. Idris, and H. Z. Abdullah, "Effect of sulphuric acid concentration on anodised titanium for biomedical application," in Proceedings of the Third International Conference on Advances in Civil, Structural and Mechanical Engineering-CSM, pp. 46-50, Birmingham, UK, April 2015. 


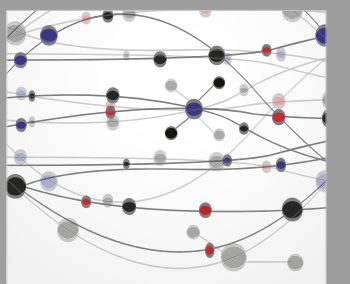

The Scientific World Journal
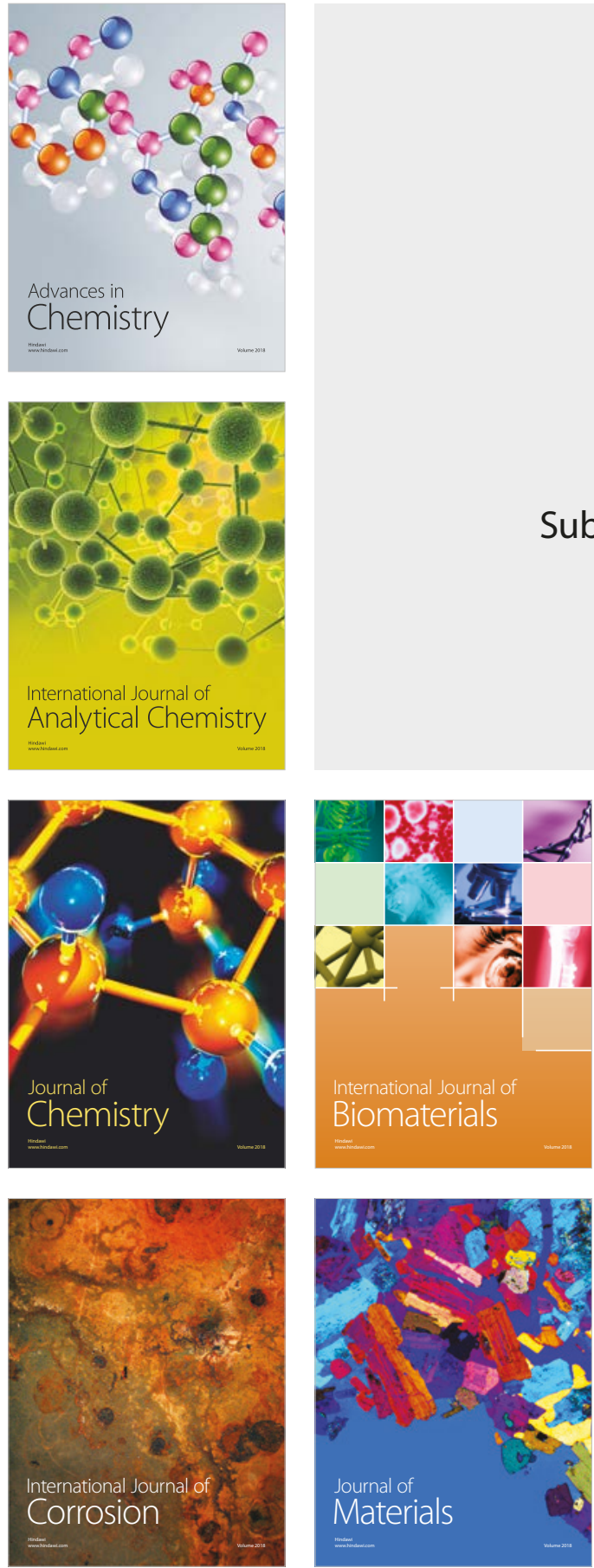

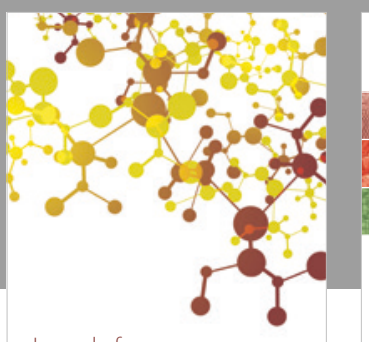

Journal of

Applied Chemistry
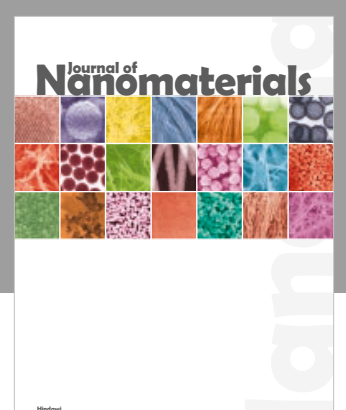

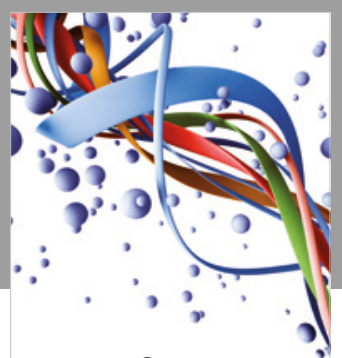

Scientifica

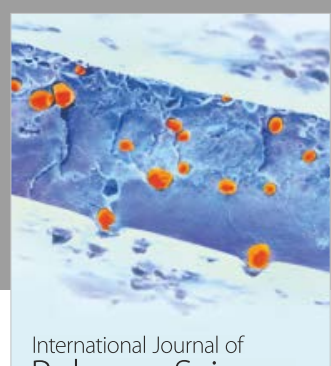

Polymer Science

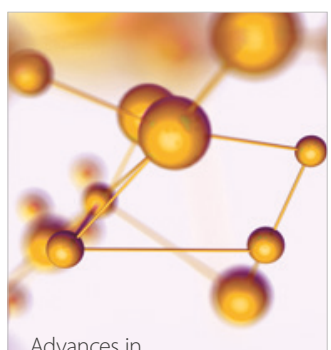

Physical Chemistry
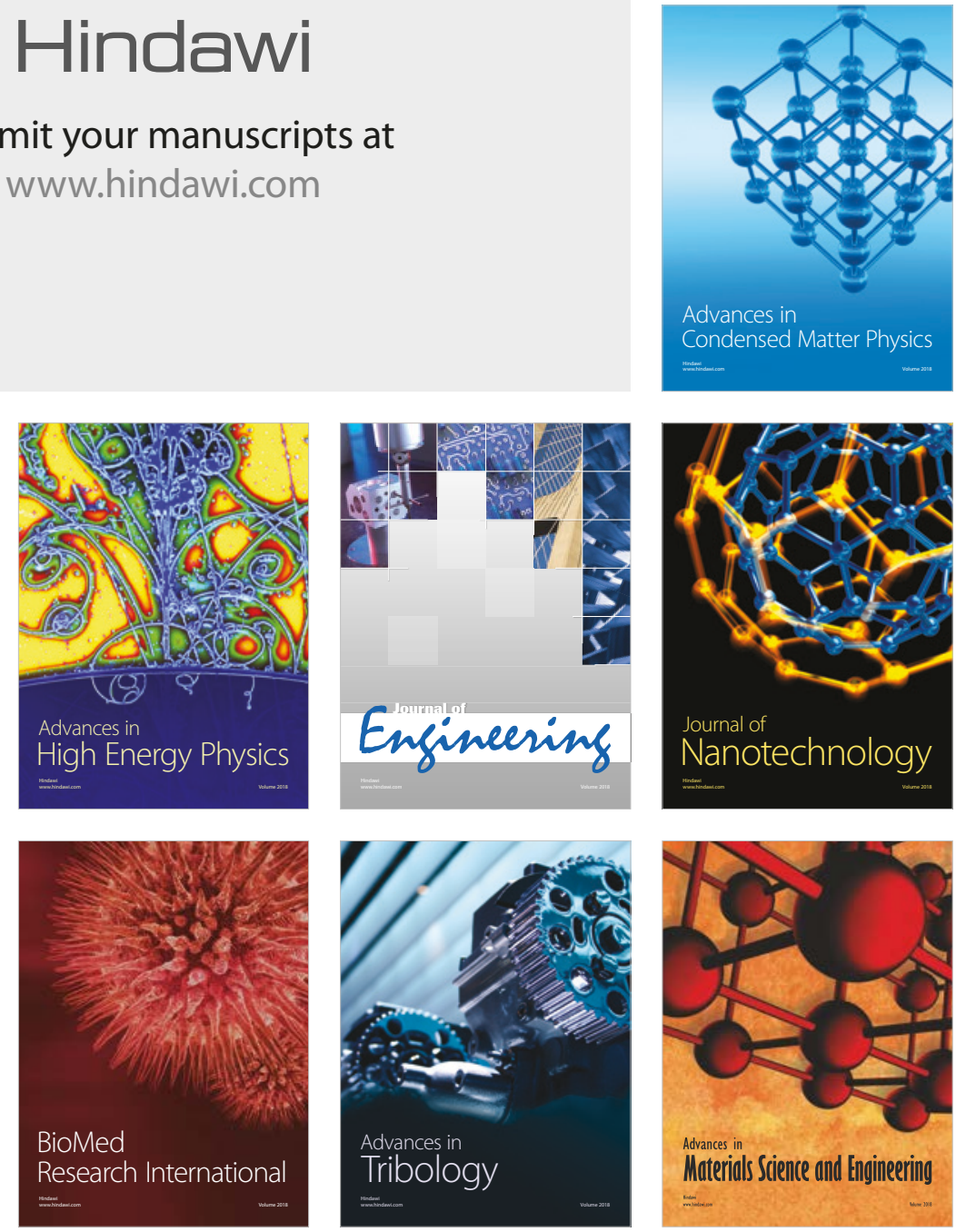